\title{
Government Audit Materiality (Part Two): Conceptual and Practical Implications of a Qualitative Materiality Framework: Seven Case Studies and a Comparative Conceptual Work
}

\author{
Yining Zhou \\ Southern Cross Business School, Southern Cross University, Riverside Campus \\ Tweed Heads, New South Wales, 2485, Australia \\ E-mail: zhou_neil@yahoo.com
}

Received: July 31, 2011

Accepted: November 2, 2011

Published: February 1, 2012

doi:10.5539/ijef.v4n2p85

URL: http://dx.doi.org/10.5539/ijef.v4n2p85

\begin{abstract}
This research is methodological in seeking a framework in assessing materiality in government auditing. The question pilots this research is: what qualitative factors are applied in government audit materiality judgment? Conceptualizing experience and knowledge of some senior government auditors, this research generates a framework comprising five qualitative factors in judging materiality in government audit. This framework is compared to prior conceptual works, and is tested in a range of realistic audit cases provided by different Chinese local audit offices. The testing results suggest the feasibility and generality of this framework in Chinese government audit context. And this framework is expected to contribute to the development of government audit standards on materiality.
\end{abstract}

Keywords: Government audit, Materiality, Qualitative factors, Audit guidelines, Multiple case studies

\section{Research Background}

Materiality is a basic concept in auditing and related to importance or significance of an amount or transaction. Financial Accounting Standards Board (FASB) defines 'materiality' as:

"The magnitude of an omission or misstatement of accounting information that, in the light of surrounding circumstances, makes it probable that the judgment of a reasonable person relying on the information would have been changed or influenced by the omission or misstatement." (Note 1)

The assessment of what is material is a matter of professional judgment. In corporate audit, materiality assessment tends to emphasize on quantitative models. A typical and influential model is 'the rule of thumb', which takes a base (such as revenues, expenditures, or assets,) and multiplies it by a percentage to set materiality thresholds. The rule of thumb is interpreted in ACCA (2007) as:

- $5 \%$ of average pre-tax income;

- $1 \%$ - $2 \%$ of total assets;

- 0.5 - $1 \%$ of total revenues

In government audit, GAGAS (6.28 a) defines materiality as:

'The concept of materiality recognizes that some matters, either individually or in the aggregate, are important for fair presentation of a subject matter or an assertion, while other matters are not important. In performing the engagement, matters that, either individually or in the aggregate, could be material to the subject matter are a primary consideration.' (Note 2)

The materiality concept was introduced into China in 2003. China National Audit Office defines it as:

'Magnitude of an omission or misstatement of information in auditees' financial statements. And this magnitude possibly influences the judgment and decision of financial statement users.' (Note 3)

However compared to materiality models in corporate audit have been well developed, government audit materiality models and guidelines are still in lack, and research on this field is scarce in both Chinese and English literature.

Materiality judgement in government audit differs from corporate audit in some aspects. An evident aspect is that 'government auditors tend to use much stricter materiality thresholds than corporate auditors' (Relmond \& 
VanDaniker 1994). This difference is also addressed in GAGAS (6.28 b), 'In engagements performed in accordance with GAGAS, it may be appropriate to use lower materiality levels as compared with the materiality levels used in non-GAGAS engagements'

Another evident difference, from practical experience of the government auditors interviewed, is that government auditors tend to adopt qualitative factors in assessing materiality. An inherent reason may be: on behalf of the public interests, government auditors are under far more pressure for accountability than corporate auditors responsible only for individual companies and their relevant shareholders. This situation reflects DeZoort et al (2006)'s argument, "(a) higher level of accountability pressure may contribute to auditors' emphasis on qualitative materiality judgment." It thus suggests a possible government audit materiality model focusing on qualitative factors.

\section{Research Method}

The research question that pilots this study is 'what qualitative factors are applied in materiality judgment on government audit?' To answer this question, I need to conceptualize the government auditors' experience and the reports on government audit cases. It leads to a qualitative research, for qualitative research approaches involve "an array of interpretive techniques which seek to describe, decode, translate and otherwise come to terms with the meaning, not the frequency, of certain more or less naturally occurring phenomena in the social world' (Van Maanen 1983, p. 9). Consistent with this view, those 'qualitative factors' that I seek are terms with the meanings, as descriptions, decodes, and translations of the realistic audits cases on materiality judgement.

This research can be divided to two stages. Stage one is the conceptualization process. The qualitative materiality factors are conceptualized from the in-depth non-structured interviews with senior government auditors who provide their experiences on how they identify or distinguish material issues during the government audit projects. This process is constructive: the knowledge is co-created by the researcher (inquirer) and the interviewees (participants) during the inquiry process (Denzin \& Lincoln 2003).

In the first stage, a comparative study is conducted between the qualitative framework conceptualized and prior conceptual work. As Collier (1993) note, the majority of qualitative research relies on some type of comparison either to establish regularities, categorizations, and links or to understand phenomena within the context they are observed and experienced. This comparative study aims to further our understandings on materiality judgments on government audits by linking and comparing this framework to other researchers' identical ideas.

Stage two is a multiple case study. This part involves seven realistic audit cases in Chinese governmental context. Case study research is an in-depth and contextually informed examination of specific organizations or events that explicitly address theory (Cooper and Morgan 2008); and multiple case study aims at elaboration, testing or generation of generalizable theoretical constructs by comparing (replicating) a number of cases (Stoecker 1991). In consistence with their view points, I employ the multiple cases to test feasibility and generality of the qualitative framework.

\section{Conceptual Implications of a Qualitative Factors Materiality Framework}

\subsection{Conceptualizing the Framework}

From in-depth interviews with some senior government auditors in a Chinese audit office, I conceptualize their experience into following five qualitative factors:

(1) Political significance

Auditors should distinguish high politically sensitive areas or items/accounts/transactions, which should be judged as material. Interviewees (senior auditors) achieve a consensus on the emphasis of politics on the materiality assessment. They stress that government auditors must be political sensitive on the auditing. "They (government auditors) are required to understand and be familiar relevant laws, policies and executive rules. Such requirements are a minimum for an eligible government auditor. They (government auditors) must be much sensitive for politics." a senior government auditor noted on our interview.

(2) Public Focus

Under public accountability, government auditors should distinguish those areas /items that generate significant social influence and public concerns. For example, issues extensively exposed in the media should be considered material. An interviewee noted, "There should be a difference between public issue and political issue. Some political sensitive areas may not be public focus, for citizens are often lack of the knowledge and interests to perceive these political issues on a macro perspective." Some interviewees noted that although public focuses are not necessarily political significant, there are not a distinct point to differentiate both factors. For example, an 
interviewee noted, "The increase of public concerns will often lead to the concerns of political leaders, and then the public issue may become politically significant."

\section{(3) Restrictedness of funds}

Restrictedness of funds is also critical for materiality assessment. There are 'forbidden funds' that are kept in some entities but must be spent in specific methods. For example, 'disaster funds' in must be spent for disaster victims; 'land funds' must be compensated for landlords, who sell land to the government. Accounts of these funds are often considered material. Other funds can be used in a relatively flexible way. Accounts of these 'flexible funds' are often considered as immaterial items. And therefore government auditors would set relatively low materiality threshold on forbidden funds, while higher materiality thresholds on flexible funds.

From auditors' experience, there exist two ways to identify 'forbidden funds': government declaration and auditors' judgment. In some cases, the upper government (the central government and province governments) declare a forbidden fund when this fund is released to the local governments and public entities. An official notion on such money is called 'specific fund with specific purpose'. Sometimes without a clear and distinct government declaration, auditors can judge forbidden funds by considering the relevant fiscal policies and disciplines.

\section{(4) Insufficiency of internal control}

For an auditee, insufficient internal control aspects potentially generate invalid or unreliable data that are leading to intentional error. For example, in an audit of a city-owned company, auditors found serious problems in inventory management procedures, which allowed products to be delivered with only a signature of the director accountant. Considering the inventory account as material, auditors eventually discovered a crime that a manager imitated the signature and 'stole' the inventory product in a value of 2 million RMB. Some interviewees pointed out that an assessment of the internal control system is often a necessary part in judging planning materiality. As one noted, "A better internal control system means less error especially systematic and intention errors for the accounting information. The effectiveness of internal control suggests less audit risk from the errors and misstatements of information. We often concern more and set higher materiality level for those areas that imply lack of internal control."

\section{(5) Experience}

Auditors often judge material accounts/transactions with reference to their past experience. A common method is to benchmark the audit cases or situations with similar cases that they (or other government auditors) once experienced.

\subsection{A Comparison to Prior Conceptual Works}

\section{Insert Table 1 Here}

Two factors in this framework, political significance and public focus, seem relevant to the qualitative factors that Relmond \& VanDaniker (1994) suggest in their survey on USA government auditors (they suggest three qualitative factors: political sensitivity, media, and litigation). However, different from Relmond \& VanDaniker's suggestion in US context, Chinese government auditors do not care much about the litigation that US auditors worry. An explanation is that litigation against government auditors or audit offices seldom happens in China, for they are considered high professional and representing justice. Furthermore, the notion 'public focus' here tends to be more inclusive than 'media (exposure)', for media exposure is one of indicators of public focus. It is worth observing that influence of local media in some Chinese areas are limited, news often spread through local communities in terms of personal communications rather than media exposure.

In USA, Government Auditing Standards (GAGAS) indicates that materiality can be affected by some factors including "the public accountability of the entity, the various legal and regulatory requirements, and the visibility and sensitivity of governmental programs, activities, and functions" (GAGAS, 6.28 b). The first factor, "public accountability of the auditee entity", can be understood as considerations of "political significance" and "public focus" in the auditee entity level. Moreover, 'governmental activities' are reflected directly on how the government as auditee deals with the public funds. By differentiating "forbidden funds" from the 'flexible funds', the typology of government funds is itself a process of identifying legal and regulatory requirement and sensitivity and visibility of governmental behaviour. From this viewpoint, "restrictedness of funds" can interpret these non-financial factors by transferring them into financial considerations.

Internal control inefficiency is related to materiality by audit control risk. Control risk is defined as the risk that a material misstatement could occur in an assertion, either individually or when aggregated with other misstatements, and not be prevented, detected, or corrected on a timely basis by the entity's internal control structure (ASA 200. 
38(b); ISA 200.29). And in some situations where internal control activity is incomplete or this activity is ineffective, auditors should suspect the auditability of accounting records (O'Reilly et al, 1999). Thus, effective internal controls reduce control risk (Leung et al 2009), and hereby reduce the possibility of occurring of material errors that result from control deficiency or failure. Krogstad et al (1984) identifies a similar term, 'the state of internal control', as a significant non-financial factor that influences the materiality judgments.

The evident influence of auditors' experience on materiality judgment has been recognized by prior experimental studies (e.g., Messier 1983; Krogstad et al 1984; Carpenter at al 1994). Messier (1983) distinguishes experience as an important non-financial characteristic in judging materiality, especially in less frequent and less structured situations. The government audit context, where practical materiality guidance is lacking, vague, and little developed, is in what Messier (1983) describes as 'less structured situations'. In this regard, considered government audit in absence of normative materiality guidelines and models, government auditors benefit significantly from their experience for 'experience improves self-insight, consistency and consensus in materiality judgment' (Iskandar \& Iselin 1999, p.237).

\section{Practical Implications: A Multiple Case Study}

This framework is tested by seven realistic audit cases from different audit offices in China, and the results show the feasibility and generality of this framework.

\subsection{Case One: A Water Conservancy Station (Note 4)}

In 2005 there was an audit on a local water office which managed several water conservancy stations. From preliminary audit evidence, auditors judged one station as material item. Situations were described as:

Political significance and Public focus

Water conservancy is a political sensitive field and directly related to agriculture and anti-flood, both are focuses of government policies. The anti-flood construction project, which was managed by the station, involves emigration of local residents. Emigration issues are also politically sensitive and a publicly concerned.

\section{Restrictedness of funds and internal control insufficiency}

In investigating the subject 'receivable', auditors found that this station did not spend the 'emigration fund' to compensate for local residents to rebuild their house, but 'lent' this fund to some entities and persons. This fund is forbidden fund. And the lending lacked of relevant procedures. The station did not require borrowing parties to provide sufficient evidence on their credit.

\section{Experience}

The station lent 'emigration fund' in amount of 3.7 million RMB, with 2.8 million RMB still receivable at the time of audit. Some were non-interest borrowing. One person borrowed the major part of this fund. And this person was the contractor for the construction project. From past experience, it might involve illegal trade-off between the contractor and the station.

\section{Actions and Results}

The audit team transferred this case to prosecutors in law office. Prosecutors and auditors eventually found that the contractor (major borrower) bribed some officials of water office.

\subsection{Case Two: A Problematic Account (Note 5)}

In 2003, in an audit for a town government, auditors judged that the item 'government grant to leading agricultural businesses' should be material. Situations were described as:

\section{Experience}

This item was not listed in the governmental budget plan.

\section{Experience}

This grant, in value of 6 million RMB, sourced from profits of two companies (say, A \& B), and was distributed to another town-owned company. It seemed unusual for this money transferred from and to the three companies.

\section{Actions and Results}

Auditors conducted an extensive audit to the town-owned company which received this grant. They found that this grant, after being received, was put forward to the subject 'payable', and then was paid to a person, the owner of the two companies (A \& B). That is, the owner distributed the profit to the government, but he would get it back in 
terms of governmental grant. In this way, the owner 'saved' the tax about 1.2 million RMB. After this issue was disclosed, the loss in tax was called back. And the owner and responsible government officers were punished.

\subsection{Case Three: The Student Restaurant (Note 6)}

In 2007, auditors conduct an audit on a local primary school. The 'student restaurant' was judged as material item. Situations of the restaurant were:

Public focus

Student restaurant is an educational issue relevant to students' health and educational fund. It concerns local communities especially families.

\section{Experience (benchmarking)}

Accounts in monthly financial statements of the restaurant did not match bank accounts. And the differences were relatively large.

\section{Experience}

The annual record was from September 2006 to October 2007. But school year should be from September 2006 to August 2007.

\section{Experience}

The bookkeeper was unskillful and unqualified. However there was not even an adjustment or change in the handwriting records in the ledger books. The books are too neat. Auditors suspected that these books were not original but 'falsified'.

Actions and Results:

Auditors discovered that during 2006 to 2007, the invoices on purchasing raw materials (vegetable, rice and oil) were falsified. And the restaurant income from student dining fees was 3.8 million RMB, of which 0.7 RMB had been occupied illegally by responsible staff.

\subsection{Case Four: Training and Re-Employment Project (Note 7)}

In 2008, Wuhan Branch of National Audit Office conducted an audit on a local labour office. From the preliminary audit evidence, the auditors considered the training and re-employment project as material issue. The situations were described as:

Political significance

This project was in the background of China government's reformation on nation-owned companies. For some companies, ownerships were changed and old management systems were reconstructed. During this reformation period, a lot of employees lost their jobs. This project was established to provide opportunities for them to find a new job by equipping them new skills.

\section{Internal control inefficiency and experience}

This project was in association with some hotels which would recruit the trainees and obtain governmental grants as rewards for the recruitment. But auditors found problems in the training project. Some trainees had been employed before they attended the project. Some trainees signed two same re-employment contracts (likely to increase the trainee number). The signatures of different trainees looked like from one person. A hotel general manager pretended to be the trainee and signed the re-employment contract with the hotel, which he was managing.

\section{Actions and results}

Auditors further investigated the trainee records and found the incorrect information. The project director eventually confessed that he and some hotels committed the government grant cheat by falsifying trainee records and documents.

\subsection{Case Five: A Local Educational Office (Note 8)}

Huazhou Audit Office conducted an audit on a local educational office. The auditors considered the basic education department as a material issue after reviewing the preliminary audit evidence.

Public focus

This department was managing all local schools and direct influencing the public especially those schoolchildren families.

Inefficiency of internal control 
The local educational office offered this department a special right to collect admin and other fees from schools. It was an intervention with the government policy that indicates only the education office headquarters keep this right.

\section{Inefficiency of internal control}

The departmental accountant was not included in the general accounts of the educational office. It was also found that the office accountant cannot acknowledge the financial performance of this department. The department kept the ledger details.

\section{Experience}

The government auditor required the departmental ledger, but the department director refused to provide it. From auditors' experience, the refusal to cooperation with government auditors implied serious problems that the auditee tries to hide.

Actions and results

The auditors collected the data of department bank account and the some staff's personal bank accounts from the local bands. Auditors found that the director had deposited into his personal account a large amount of cash equal to his salary of 10 years. And based on the audit evidence from some local schools, the audit team also confirmed that the department directly collected money in terms of exam design fees from local schools. The auditors refereed this matter to law enforcement officials and conducted a further investigation in support of law office. The department director eventually confessed the fraud: this large amount of money in his bank account was part of the exam design fees from local school.

\subsection{Case Six: The Anti-Drought Team (Note 9)}

Anti-drought team is a department of the local water office. Auditors received a confidential report from a member of this team, alleging that the team captain was appropriating the national disaster funds as his own. The auditors decided to conduct an extensive audit on the water office. They considered the anti-drought team as the material issue.

\section{Political significance}

Anti-drought projects directly influence agricultural development and the life of farmers in this area, and farmers constitute the major population of this area. The political impacts are significant for these projects.

\section{Restrictedness of funds}

As a kind of disaster funds, anti-drought funds are considered a forbidden fund in China.

\section{Inefficiency of internal control and experience}

The captain and the team accountants declared that they spent all anti-drought funds on purchasing anti-drought machines. However auditors found that all these funds had been withdrawn in cash from the team bank account; it look unusual for buying machinery involves a large amount of money and normally via bank transfers rather than cash.

\section{Inefficiency of internal control and experience}

After a physical inspect on the inventory, auditors found some machines old or lacking trademarks. Moreover, some invoices on the machinery purchase were not from supplier but from retail market (In China, invoices from factories were marked 'industrial', while from retail market marked 'commercial'. The 'commercial' invoices are easily to be obtained and falsified), although the auditee should show industrial invoices on purchasing machines from suppliers.

\section{Actions and Results}

Auditors requested information from the tax authority, and found that the tax account on purchasing the machines cannot match the auditees' records. The tax account indicated a lower expenditure and fewer machines than in the team financial statements. It strongly suggests some funds were being illegally used or occupied. Auditors reported this matter to local law enforcement and conducted a further investigation. The team captain eventually confessed that he illegally appropriated some disaster funds and bribe relevant officials. He also confessed that, to deceive government auditors, he borrowed most machines from other entities for the physical inventory inspect, and also falsified the original invoices.

\subsection{Case Seven: The Chandelier (Note 10)}

On an audit of a public hotel, a special chandelier in the hotel lobby attracted the eyesight of auditors. In the hotel records, this chandelier was made of crystal. Auditors identified the following situations and considered it material. 


\section{Inefficiency of internal control}

The chandelier purchase should be open to all local suppliers to ensure a reasonable price. But only one supplier was allowed to attend the transaction. The hotel kept it secret to other suppliers. And the supplier has never provided relevant technical documents on this luxury chandelier, such as maintenance brochures and certificates. And hotel never required such documents from the supplier.

\section{Experience}

The hotel made this purchase during the time when it met financial problems and cash shortage. It was unusual for it to spend such large money for a decorative item in this time.

\section{Actions and results}

The auditors reviewed the supplier's account. They found that the supplier did not manufactured it but had purchased this chandelier from another city from only 0.3 million RMB and had sold it to the hotel for 1 million. There was a gap between the market value and the purchase price. The auditor invited a specialist to assess the chandelier's value. The specialist asserted that it was made of glass, not crystal. It indicates fraud. In support of law enforcement official, the hotel manager confessed he received bribery from the supplier and make the transaction at an inflated price.

Insert Table 2 Here

\section{Conclusion}

Materiality application is contextual. The models and guidelines that developed from corporate audit context may not be applicable to government audit due to the different contextual situations. This research is a positive response to Relmond \& VanDaniker (1994)'s calling of innovation on materiality guidelines in government auditing. Grounded on experience and knowledge of government auditors, this research conceptualizes five qualitative factors, which are further compared to prior conceptual works on audit materiality.

As Zartman (2005) points out, the only way to test and reinforce concepts' and theories' claims to normal regularity rather than exceptionality is to test them a number of cases. A multiple case study thus exhibits the advantage of in-depth analysis on whether or not this materiality framework is applicable in government audit practice.

This research tests the framework in a range of realistic audit cases. The testing results imply the generalizability and feasibility of these factors that are conceptualized from living experience of the government auditors who I interviewed. This study may be a reference to government auditors in practice, and be a potential contribution to future government audit standards and guidelines. However, there are two limitations for this study. One is that seven cases may not construct a 'rich description' to generate a widely acceptable conceptual frame (in this study, the five qualitative factors). To achieve this aim, it is needed to advance the work on conceptualizing experience and knowledge of government audit. Secondly, for conceptualization of this framework is grounded on the experience and cases in Chinese context, generalization of this framework requires a further research on government audit of other countries in regard of cultural and political differences.

\section{Acknowledgement}

I would thank Gangying Zhou, the retired head government auditor of Huazhou, for his advice and assistance in this study. I would also thank all interviewees who contributed their government auditing experience and opinions to this study. Their participation is critical to both part one and two of this research project on applying and exploring the concept of materiality in to government audit setting.

\section{References}

ACCA. (2007). Audit and Assurance. London:BPP.

ASA 200 Objective and General Principles: Governing an Audit of a Financial Report.

Bryman, A., \& Bell, E. (2003). Business Research Methods, Oxford University Press.

Carpenter, B., Dirsmith, M., \& Gupta, P. (1994). Materiality judgments and audit firm culture: social-behavioural and political perspectives. Accounting, Organization and Society, vol.19, iss.4, pp.355-380.

Chewning, E., \& Higgs, J. (2002). What does materiality really mean?. The Journal of Corporate Accounting \& Finance, vol.13, iss.4, pp.61- 71 .

Chinese National Audit Office. (2003). Chinese Audit Principles and Standards 2003. available at $<$ www.audit.gov.cn>. 
Collier, D. (1993). The comparative method. In A.Finifeter (Ed.), Political science: State of the discipline II, pp. 105 - 119. APSA, Washington.

Cooper, D.J., \& Morgan, W. (2008). Case study in accounting. Accounting Horizons, vol. 22, iss. 2, pp. 159 - 178.

Denzin, N.K., \& Lincoln, Y.S. (2003). introduction: the discipline and practice of qualitative research, in N.K. Denzin, \& Y.S. Lincoln (Eds). Strategies of Qualitative Inquiry, (2nd ed), pp. 1 - 45, Sage, Colifornia.

DeZoort, T., Harrison, P., \& Taylor, M. (2006). Accountability \& aduitors' materiality judgements: the effects of differential pressure strength on conservatism, variability, and effect. Accounting, Organisation and Society, vol.31, iss.1, pp. 373 - 390. http://dx.doi.org/ 10.1016/j.aos.2005.09.001.

Easterby-Smith, M., Thorpe, R., \& Lowe, A. (2002). Management Research: an introduction. SAGE Publishing, London.

Erisenhardt, J. (1989). Building theories from case study research. Academy of Management Review, vol.14, iss.4, pp. $530-552$.

Financial Accounting Standards Board. (1980). Qualitative characteristics of accounting, Statement of Financial Accounting Concepts, no.2, FASB.

Government Accounting Standard Board. (1994). Codification of Government Accounting and Financial Reporting Standard, June, Norwalk, CT.

ISA 200. Overall Objective of the Independent Auditor, and the Conduct of an Audit in Accordance with International Standards on Auditing.

Iselin, E., \& Iskandar, T. (2000). Auditors' recognition and disclosure materiality thresholds: their magnitude and the effects of industry. The British Accounting Review, vol.32, iss.3, pp. $289-391$.

Krogstad, J.L., Ettenson, R. T., \& Shanteau, J. (1984). Context and experience in auditors materiality judgments. Auditing: a Journal of Practice \& Theory, vol.4, iss.1, pp. 54-73.

Leung, P., Coram, P., Cooper, B., \& Richardson, P. (2009). Modern Auditing \& Assurance Services ( $4^{\text {th }}$ ed), Milton: John Wiley \& Sons Australia.

Messier, W. (1983). The effect of experience and firm type on materiality/disclosure judgments. Journal of Accounting Research, autumn, pp. 611-618.

Messier, W., Martinov-Bennie, N., \& Eilifsen, A. (2005). A review and integration of empirical research on materiality: two decades later. Auditing: a Journal of Practice and Theory, vol.24, iss.2, pp. $153-187$.

O'Reilly, V.M., Winograd, B.N., Gerson, J.S., \& Jaenicke, H.R. (1999). Montgomery's Auditing, (12 ${ }^{\text {th }}$ ed), John Wiley \& Sons Inc.

Relmond, K., \& VanDaniker, R. (1994). Materiality in government auditing, Journal of Accountancy Feb, pp 7176.

Stoecker, R. (1991). Evaluating and rethinking the case study. Sociological Review. vol 39, iss.1, pp.88 - 112. http://dx.doi.org/10.1111/j.1467-954X.1991.tb02970.x

Van Maanen, J. (1983). Qualitative Methodology, Sage, London.

Zartman, W. (2005). Comparative case studies. International Negotiation, vol.10, pp. 3 - 5.

Zhou, Y., \& Zhou, G. (2011). Establishing judgments about materiality for government audits, experiences from Chinese local government auditors. International Journal of Government Auditing, vol.38, no.3, pp.9 - 14.

Zhou, Y. (2012). Government audit materiality (part one): how and why is it different from corporate audit materiality? A case study and a theoretical matrix, International Journal of Economics and Finance, vol.4, iss.1, pp 80 - 89. http://dx.doi.org/10.5539/ijef.v4n1p80

\section{Notes}

Note 1. Financial Accounting Standards Board, Original Pronouncements as Amended. Statement of Financial Accounting Concepts No. 2: Qualitative Characteristics of Accounting Information (May 1980).

Note 2. General Accepted Government Audit Standards, 6.28: Definition of Materiality.

Note 3. Chinese National Audit Office, Chinese Audit Principles and Standards (2003).

Note 4. The audit case was provided by Ningbo City Audit Office. This case was published in Chinese language in the website of National Audit Office (NAO). The author of this paper is responsible for the translation. 
Note 5. Ningbo City Audit Office provided this case, which was published in NAO website in Chinese language. The author of this paper is responsible for the translation work of this case.

Note 6. This case was provided by Xiaoshan District Audit Office and published in NAO website in the language of Chinese. The author of this paper is responsible for the translation of this case.

Note 7. Wuhan Branch of NAO provided this audit case, which was published in NAO website in Chinese language. The author of this paper is responsible for the translation work of this case.

Note 8. Auditors in Huazhou City Audit Office provided this case in an oral narrative. I am responsible to the editing and translation of this case. Gangying Zhou also contributed to editing of this case and following two cases. The three cases are involved in a professional report that we authored for INTOSAI / International Journal of Government Auditing.

Note 9. this case is provided by Shengyang branch of China National Audit Office (CNAO). This case firstly was published in Chinese language on CNAO website. It is the responsibility of the author in this article to translate, edit and analyse this case.

Note 10. this case is provided by Changzhou City Audit office. It is first reported on CNAO website, in the language of Chinese. It is the responsibility of the author of this article to translate, edit, and analyse this case.

Table 1. A comparison between the qualitative framework and prior conceptual works

\begin{tabular}{|l|l|}
\hline $\begin{array}{l}\text { The five qualitative factors } \\
\text { materiality framework }\end{array}$ & \multicolumn{1}{|c|}{ Prior conceptual works } \\
\hline Political significance & $\begin{array}{l}\text { "Political significance" (Relmond \& VanDaniker 1994) } \\
\text { "Public accountability of the entity" (GAGAS, 6.28 b) }\end{array}$ \\
\hline Public focus & $\begin{array}{l}\text { "media" (Relmond \& VanDaniker 1994) } \\
\text { "public accountability of the entity" (GAGAS, 6.28 b) }\end{array}$ \\
\hline Restrictedness of funds & $\begin{array}{l}\text { "various legal and regulatory requirements" (GAGAS, 6.28b) } \\
\text { "visibility and sensitivity of government programs, activities, and functions" (GAGAS, 6.28b) }\end{array}$ \\
\hline Inefficiency of internal control & $\begin{array}{l}\text { Control risk (ASA 200.38 (b); ISA 200.29; Leung et al 2009) } \\
\text { "the state of internal control" (Krogstad et al 1984) }\end{array}$ \\
\hline Experience & $\begin{array}{l}\text { Experimental research shows experience influence on audit materiality judgement (Messier 1983; Krogstad } \\
\text { et al 1984; Carpenter et al 1994) } \\
\text { Experience as an important non-financial characteristic in judging materiality especially in less frequent and } \\
\text { less structured situations (Messier 1983) } \\
\text { "experience improves self-insight, consistency and consensus in materiality judgment" (Iskandar \& Iselin } \\
1999)\end{array}$ \\
\hline
\end{tabular}

Note: the "litigation" as a qualitative materiality factor suggested by Relmond \& VanDaniker (1994) seems not applicable in Chinese government audit context.

Table 2. The multiple case study tests the feasibility of the qualitative materiality framework

\begin{tabular}{|l|l|l|l|l|l|}
\hline \multicolumn{1}{|c|}{ Audit Cases } & Political significance & Public focus & Restrictedness of funds & Inefficiency of internal control & Experience \\
\hline 1. Water station & $\sqrt{ }$ & $\sqrt{ }$ & $\sqrt{ }$ & $\sqrt{ }$ & $\sqrt{ }$ \\
\hline 2. a Problematic account & & & & & \\
\hline 3. a student restaurant & & $\sqrt{ }$ & & & $\sqrt{ }$ \\
\hline 4. training re-employ project & $\sqrt{ }$ & & & $\sqrt{ }$ & $\sqrt{ }$ \\
\hline 5. education office & & $\sqrt{ }$ & & $\sqrt{ }$ & $\sqrt{ }$ \\
\hline 6. an anti-drought team & $\sqrt{ }$ & & $\sqrt{ }$ & $\sqrt{ }$ & $\sqrt{ }$ \\
\hline 7. the chandelier & & & & & $\sqrt{ }$ \\
\hline
\end{tabular}

